\title{
Development of Coatings Marine Antifouling Based on Perfluorinated Surfactants Synthesis and Physicochemical Study
}

\author{
Abdelkader Bacha1, Rachid Méghabar ${ }^{2}$ \\ ${ }^{1}$ Chemistry Laboratory, Faculty of Sciences and Technology, University of Djelfa, Djelfa, Algeria \\ ${ }^{2}$ Laboratory of Polymer Chemistry, University of Es-Senia, Oran, Algeria \\ Email: mbamalo@yahoo.com
}

Received 3 January 2014; revised 2 February 2014; accepted 1 March 2014

Copyright (C) 2014 by authors and Scientific Research Publishing Inc.

This work is licensed under the Creative Commons Attribution International License (CC BY). http://creativecommons.org/licenses/by/4.0/

(c) (7) Open Access

\section{Abstract}

The fight against dirt settling on the hulls of ships and more generally on all underwater structures is more than $\mathbf{2 0 0 0}$ years. The need for effective antifouling paints, which prevents the establishment and growth of marine organisms on submerged structures, is universally recognized. In this work, we synthesize two perfluorinated surfactants from simple monomers. After describing the reactions, we discuss the different analyzes of the proton nuclear magnetic resonance $\left({ }^{1} \mathrm{H}\right.$ NMR), the fluorine nuclear magnetic resonance (NMR ${ }^{19} \mathrm{~F}$ ), gel permeation chromatography (GPC) and the light scattering (LS) at a fixed angle 90. The glass transition temperature of the two surfactants diethylallylphosphonate and allylamine are obtained by Differential Scanning Calorimetry (DSC). Antifouling paint properties were followed by exposure of the plates to the marine environment by visual observation.

\section{Keywords}

Diethylallylphosphonate, Allylamine, Antifouling, Glass Transition Temperature, Salt Water, Aluminum Plates, Differential Scanning Calorimetry, Critical Micelle Concentration (CMC)

\section{Introduction}

Since the late sixties of the last century and until the end of 2007, biocidal organotin based compounds, especially tributyltin (TBT) were most widely used in paint formulations because of their effectiveness, and they can last up to five years (self-polishing paints) [1] [2]. But it was regulated at the international level since 1990 due to serious consequences on the aquatic ecosystem, such as imposex in female gastropods many anomalies or 
calcification of the shell oysters $C$. gigas [3]-[6]. Many countries have therefore banned the use of TBT-based paints. In 2001, the International Maritime Organization (IMO) and the Committee for the Protection of the Marine Environment (MEPC) have provided for the prohibition of the use of TBT antifouling biocide on all ships. The ban was put in place in 2003, with total from January 2008 ban, which has led to an increase in vessels using coatings without organotin compounds containing copper combined with other organic biocides called boosters.

Fouling is also an important factor for corrosion coating ships' hulls. All these effects thus lead to a clean hull and frequent re-states that have significant economic impact [7].

Other groups are also known for their antibacterial activity to meet this criterion, such as the phosphonium and quaternary ammoniums, sulfoniums, phosphonats and carboxylates. The quaternary ammonium salts are the most commonly used ones [8].

We have taken this knowledge and modified in order to improve the technical implementation and in order to adapt to an application in the field of antifouling paints. To do so, the synthesis process by radical telomerization coatings was recommended.

\section{Experimentation}

\subsection{Materials}

The perfluorinated surfactants of diethylallylphosphonate (TPADP) and of allylamine (TPAAm) were synthesized in the laboratory of the department of material sciences, Faculty of Science and Technology (University Djelfa (Algeria)) this synthesis is described in detail in Section 2.3 and 2.4 (Figure 1).

The products were vacuum distilled before use, and stored at $0^{\circ} \mathrm{C}$ to avoid thermal polymerization. Azobisisobutyronitrile (AIBN) and perfluorinated thiol were used respectively as a free radical initiator and transfer agent.

The tetrahydofurane (THF), pentane, acetonitrile and ether (Merck) were analytical products and used directly without further purification. The water was deionized.

\subsection{Measure}

Proton NMR measurements were performed on a Brucker WB spectrometer 360 (ref. Internal $\mathrm{CDCl}_{3}$ ). Chemical shifts are expressed as $10^{-6}$.

The determination of critical micelle concentrations of the two surfactants TPADP and TPAAm are given by light scattering (LS) at a fixed angle $90^{\circ}$. The optical constant of the device (in the experimental conditions used here) is $\mathrm{K}=0.735 \times 10^{2}$. The molecular weight and molecular weight distributions were determined by gel permeation chromatography (GPC), the device with THF as eluent, flow rate: $0.8 \mathrm{ml} / \mathrm{min}$, volume of injection loop: $0.2 \mathrm{ml}, 2$ columns as support mixed gel porosity and particle size of $10 \mu$ and differential refractometer (BricePhoenix) as a concentration detector $(\lambda=632 \mathrm{~nm})$. The thermogram of Differential Scanning Calorimetry (DSC) was made on a Mettler TA 4000 model apparatus at a heating rate of $10^{\circ} \mathrm{C} / \mathrm{min}$. The glass transition temperature (Tg) was taken at the beginning of the jump corresponding to the heat capacity.

\subsection{Telomerization of Perfluorinated Diethylallylphosphonate}

$17.8 \mathrm{~g}(0.1 \mathrm{~mol})$ of allyldiéthylphosphonate were introduced with $72 \mathrm{~g}(0.151$ moles $)$ of perfluorinated thiol $\left(\mathrm{C}_{8} \mathrm{~F}_{17} \mathrm{C}_{2} \mathrm{H}_{4} \mathrm{SH}\right)$ and $(0.048 \mathrm{~mol})$ of potassium bromide and $50 \mathrm{~mL}$ of freshly distilled acetonitrile. The mixture was degassed by nitrogen for 5 minutes then heated to $40^{\circ} \mathrm{C}$.

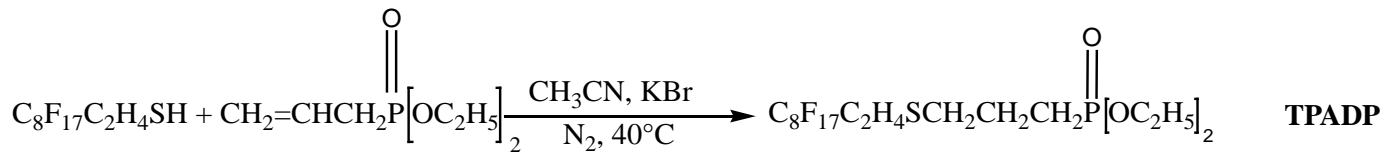

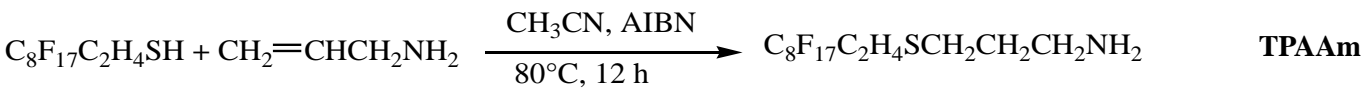

Figure 1. Representation of the telomerization reaction. 
$2.6 \mathrm{~g}(0.048 \mathrm{~mol})$ of trimethylsilyl chloride are added dropwise during $15 \mathrm{~min}$. The product obtained is purified by evaporation $\left(50^{\circ} \mathrm{C} / 20 \mathrm{mmHg}\right)$. $\mathrm{m}$ (obtained) $=14.7 \mathrm{~g}$.

RMN ${ }^{1} \mathrm{H}\left(\mathrm{CDCl}_{3}\right): \delta(\mathrm{ppm}): 1.2\left(\mathrm{t}, 3 \mathrm{H}, \mathrm{CH}_{3} \mathrm{CH}_{2} \mathrm{P}\right), 4.1$ (q, $\left.2 \mathrm{H}, \mathrm{CH}_{3} \mathrm{CH}_{2} \mathrm{P}\right)$, 2.2, 2.5 (m, 4H, $\left.\mathrm{CH}_{2} \mathrm{SCH}_{2}\right)$, 2.6, $2.8\left(\mathrm{~m}, 4 \mathrm{H}, \mathrm{C}_{8} \mathrm{~F}_{17} \mathrm{CH}_{2} \mathrm{CH}_{2} \mathrm{SCH}_{2} \mathrm{CH}_{2}\right), 1.8,1.9\left(\mathrm{~m}, 2 \mathrm{H}, \mathrm{SCH}_{2} \mathrm{CH}_{2} \mathrm{CH}_{2}\right)$.

$\underline{\mathrm{RMN}}{ }^{\mathrm{I}} \mathrm{F}\left(\mathrm{CCl}_{3}\right) \delta$ (ppm) [9]-[11]: in the solvent ${ }^{19} \mathrm{~F}$ shifts are $\mathbf{F}_{3} \mathbf{C}-(-24.2),-\mathbf{C F}_{2}(-51.0),-\left(\mathbf{C F}_{2}\right)_{3}(-53.9)$, $-\mathbf{C F}_{2}(-54.2),-\mathbf{C F}_{2}(-55.3),-\mathbf{C F}_{2}-\mathbf{S}(-57.5)$.

\subsection{Telomerization of Perfluorinated Allylamine}

$5 \mathrm{~g}(0.09 \mathrm{~mol})$ of allylamine was placed with $150 \mathrm{~mL}$ of acetonitrile, then $20 \mathrm{~g}(0.042 \mathrm{~mol})$ of perfluorinated thiol $\left(\mathrm{C}_{8} \mathrm{~F}_{17} \mathrm{C}_{2} \mathrm{H}_{4} \mathrm{SH}\right)$ dropwise in order to consume all of the monomer to $80^{\circ} \mathrm{C}$ for 12 hours with stirring. The reaction is carried out at $80^{\circ} \mathrm{C}$ in the presence of nitrogen, AIBN as initiator.

The reactants are mixed in defined proportions. After evaporation of the solvent, the product mass was obtained $\mathrm{m}=15 \mathrm{~g}$.

The surfactant TPAAm was purified by dissolving in dichlomethane.

$\mathrm{RMN}^{1} \mathrm{H}\left(\mathrm{CDCl}_{3}\right): \delta(\mathrm{ppm}): 1.5,1.9\left(\mathrm{q}, 2 \mathrm{H}, \mathrm{CH}_{2} \mathrm{~N}\right), 2.2,2.5\left(\mathrm{~m}, 4 \mathrm{H}, \mathrm{CH}_{2} \mathrm{SCH}_{2}\right), 2\left(\mathrm{~s}, 2 \mathrm{H}, \mathrm{NH}_{2}\right), 2.6,2.8(\mathrm{~m}$, $4 \mathrm{H}, \mathrm{CH}_{2} \mathrm{CH}_{2} \mathrm{SCH}_{2} \mathrm{CH}_{2}$ ).

\subsection{Determination of the Critical Micellar Concentration}

The initial solution is obtained by dissolving the product in $50 \mathrm{ml}$ of distilled THF solvent. The solutions are then diluted volumetrically in generally $3 / 4,1 / 2$ and $1 / 4$ reports, different solutions are clarified by centrifugation at 18,000 $\mathrm{t} / \mathrm{min}$ for 4 hours. The concentration range studied, respectively:

Surfactant TPADP: $0450 \times 10^{-3}$ and $6.80 \times 10^{-3} \mathrm{~g} / \mathrm{mL}$.

Surfactant TPAAm: $0175 \times 10^{-2}$ and $2.27 \times 10^{-2} \mathrm{~g} / \mathrm{mL}$.

\subsection{Preparation of Plates}

The plates used are rectangular in shape $(7.5 \mathrm{~cm} \times 6.5 \mathrm{~cm})$ aluminum, thickness $3 \mathrm{~mm}$, test paints were applied directly using a brush on the flat surface of the plate brushed with the previously glass paper, cleaned and washed with methanol. Each plate is painted on both sides in successive two layers, leaving at least 24 hours between applications.

After a drying time (one week maximum) the plates are arranged and fixed on a metal support. Plates paintings are called P1 (TPAAm) and P2 (TPADP).

The paint is prepared by dissolving the resin (35 parts) in 2-methoxypropanol (65 parts). The formulations are prepared in a laboratory dissolver DISPERMAT [12].

\subsection{Exposure to the Marine Environment}

Given the good results we have obtained in the section entitled Preparation of perfluorinated surfactant Antifouling Paints for Activates [12], we put new plates in trials following the same steps outlined in this article, by increasing the length of immersion (30 months). These plates are photographed and a study of their behavior vis-à-vis the filing of the underwater soil is performed (the immersion date January 2011).

\section{Results and Discussion}

\subsection{Synthesis Perfluorinated Surfactants Diethylallylphosphonate and Allylamine}

The choice of these two monomers is due to their numerous applications and their specific characteristics (Figure 1). They exist in form of a low volatile liquid, on the other hand, the raw resins phosphorus seriously studied for practical use in order to inhibit the flame were allyl ester type [13].

\subsection{Calculation of the Refractive Index Increment ( $\mathrm{d} n / \mathrm{d} c$ ) of Perfluorinated Surfactants}

The most commonly used method of the refractive index increment $(\mathrm{d} n / \mathrm{d} c)$ is the differential measurement: 
measurement of the difference rather than the separate measurement of the two indices of refraction (Table 1). A diagram simplifies a differential refractometer (Brice-Phoenix) is shown in figure below (Figure 2).

It comprises a light source (S) (mercury vapor lamp and filter: for $\lambda_{0}=436$ and $546 \mathrm{~nm}$ or He/Ne laser at 633 $\mathrm{nm}$ ), a font object ( $\phi$ and F), a differential chamber (C) (box with two compartments: one for solutions), a lens with aperture $(\mathrm{L})$ and a scope that identifies the deflection of the beam as it passes into the cell (V and $M$ ).

This quantity $(\mathrm{d} n / \mathrm{d} c)$ operates both in the operating results related to the techniques of light scattering in the determination of very low concentrations of the solute (in chromatography, determination of impurities, ...).

\subsection{Gel Permeation Chromatography of Perfluorinated Surfactants (TPADP) and (TPAAm)}

The chromatography device with THF eluent is a conventional apparatus (flow rate: $0.8 \mathrm{~mL} / \mathrm{min}$, the injection volume of [14] loop: $0.2 \mathrm{ml}, 2$ columns with gel as a carrier and mixed porosity particle size equal to $10 \mu$ and a differential refractometer as a detector of concentration) [14].

The chromatograms are shown in Figure 3.

It is observed in Figure 3(a) good reproducibility of measurements: no effect of concentration on the peak position, and A typical narrow and symmetrical chromatogram of a well-defined product and iso-molecular. For example, we compared the chromatogram obtained with the solution for the most dilute solution of a polystyrene (PS) of small mass.

This figure confirms the homogeneity of the product TPADP, the Ve (max) was $36.85 \mathrm{~mL}$. The apparent molecular weight (or equivalent weight PS) derived from the calibration of the columns is 1400 while the actual mass of the surfactant molecule is 900 , the polydispersity index $M w / M n=1.58$ (Table 2).

The chromatogram $b$ of the surfactant TPAAm is slightly different from that of the product TPADP, in addition to the main peak (Ve $(\max )=37.2$ volumes), a shoulder on the side of large volumes of elution is observed (low masses) on the apparent molecular mass is obtained in 1120.

This shoulder has a bimodal (Figure 3(b)), which is due to excess of thiol in the reaction mixture. The thiol was removed by selective precipitation in pentane.

\subsection{Measurement of Critical Micelle Concentrations ( $\mathrm{cmc}$ )}

The general equation for the light scattering (DDL)—for small sizes [13]—is:

$$
K^{\prime} \frac{\left(\frac{\mathrm{d} n}{\mathrm{~d} c}\right)^{2}}{\Delta I \cdot C}=\frac{1}{M}+2 A_{2} C+\cdots
$$

$K^{\prime}$ : Optical device constant $=0732 \times 10^{-2}$

$\Delta I$ : The difference between the intensity of the solution and solvent.

$M$ : The mass of the solvent.

$A_{2}$ : Second Virial coefficient giving the thermodynamic properties.

The values of scattered intensity " $I$ " depending on the concentrations are summarized in Table 3, Table 4 for the two surfactants TPADP and TPAAm respectively.

It first gets all in the field of low concentrations greater linear variation (Figure 4), then from a certain concentration a different behavior is observed: the scattered intensity increases in a significant way and tends to the formation of micelles.

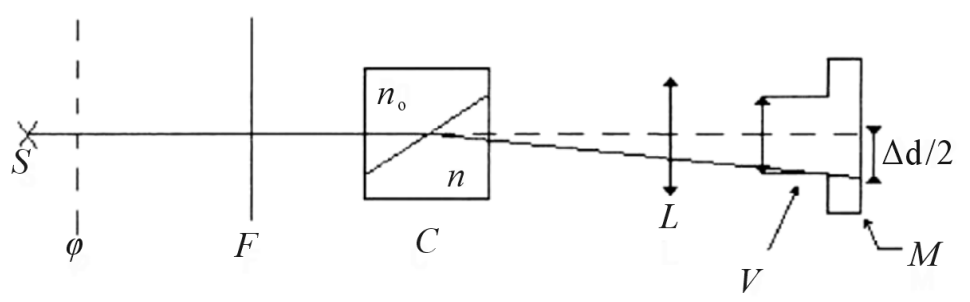

Figure 2. Diagram of a differential refractometer [13]. 


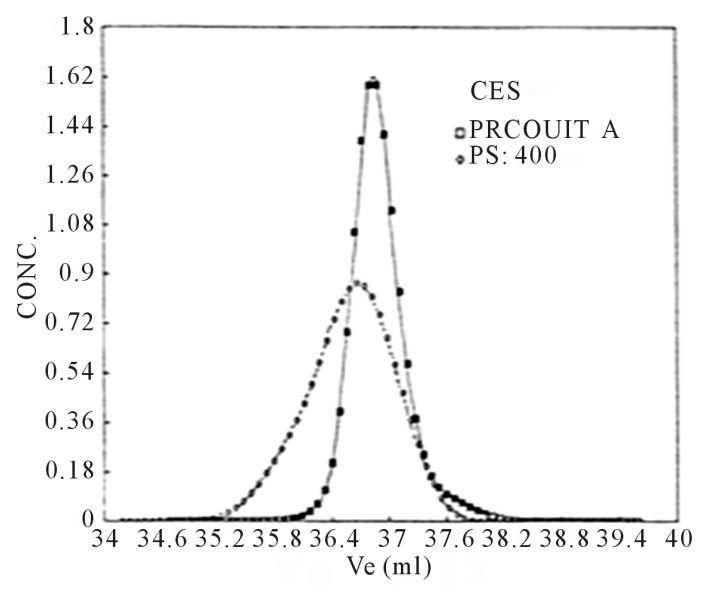

(a)

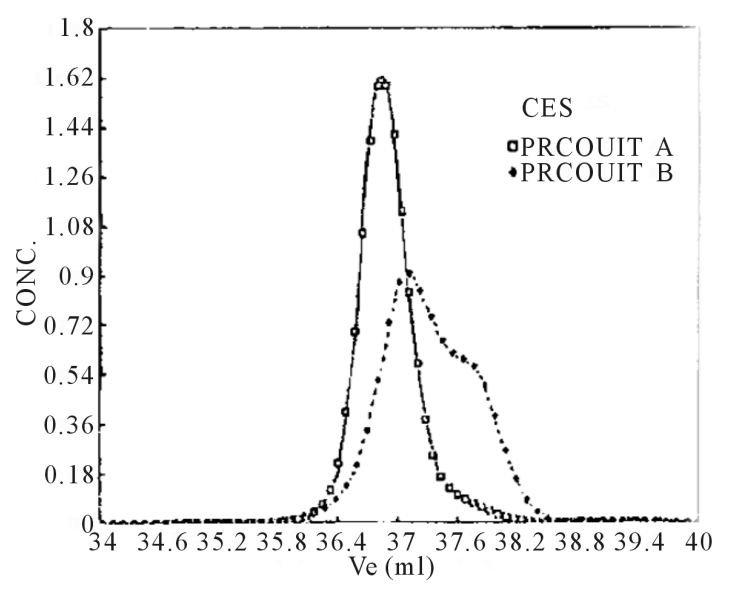

(b)

Figure 3. (a) and (b), the concentration of the two chromatograms as a function of elution volume.

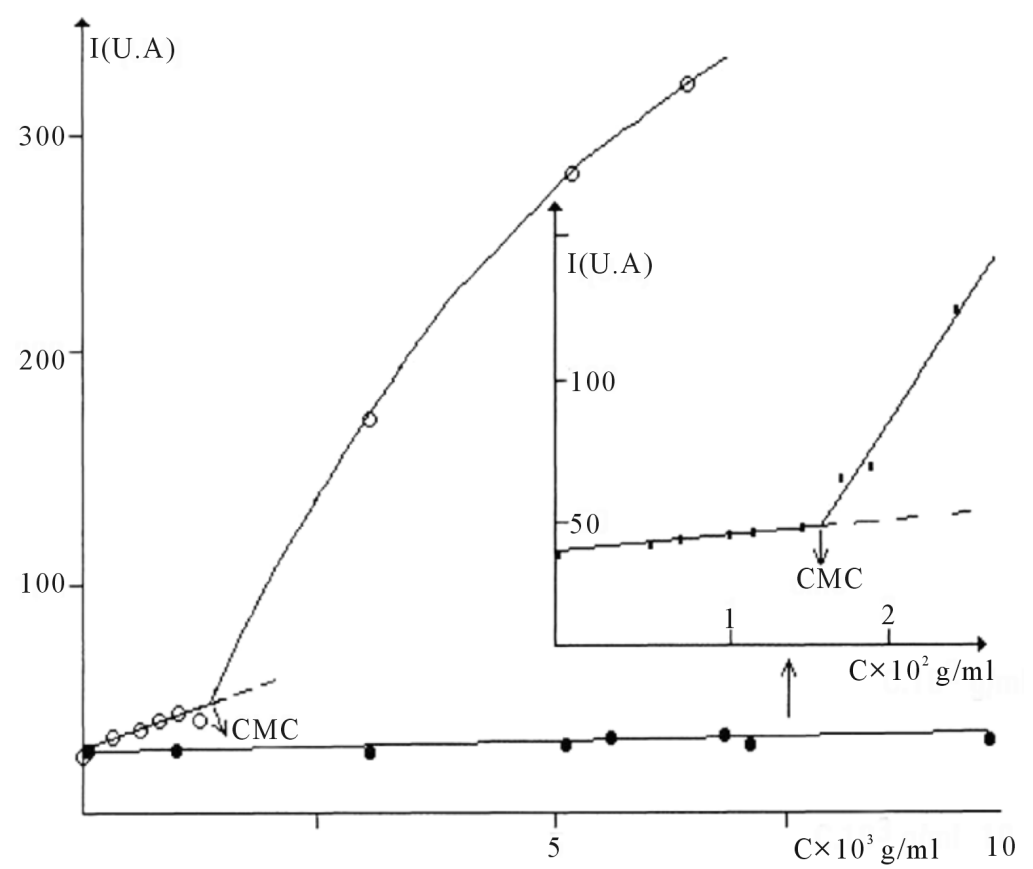

Figure 4. Evolution of the scattered intensity as a function of surfactant concentration for TPADP and TPAAm dissolved in THF.

Table 1. The values of $\mathrm{d} n / \mathrm{d} c$ of the two surfactants TPADP and TPAAm.

\begin{tabular}{ccc} 
surfactants & solvent & dn/d $\boldsymbol{c}$ \\
\hline TPADP & THF & -0.058 \\
TPAAm & THF & -0.080 \\
\hline
\end{tabular}

Table 2. Characterization and surfactants TPADPA TPAAm.

\begin{tabular}{ccc}
\hline Surfactants & $\boldsymbol{V}_{\text {el }}(\mathbf{m l})$ & $M_{w} / M_{n}$ \\
\hline TPADP & 36.85 & 1.58 \\
TPAAm & 37.20 & 1.62 \\
\hline
\end{tabular}


Table 3. cmc of the product TPADP.

\begin{tabular}{cccc}
\hline $\mathbf{c} \times \mathbf{1 0}^{\mathbf{3}} \mathbf{( g / \mathbf { m L } )}$ & $\mathbf{I}(\mathbf{\text { u.a}})$ & $\Delta \mathbf{I}(\mathbf{u . a})$ & $(\mathbf{c} / \mathbf{I}) \times \mathbf{1 0 ^ { \mathbf { 4 } }}$ \\
0.00 & $\mathrm{I}_{0}=36$ & & 0.45 \\
0.45 & 46 & 10 & 0.50 \\
0.90 & 54 & 18 & 0.48 \\
1.35 & 64 & 28 & 0.47 \\
1.70 & 72 & 36 & 0.47 \\
1.80 & 74 & 38 & \\
\hline
\end{tabular}

Table 4. Scattered intensity and the concentration (in $\mathrm{g} / \mathrm{mL}$ ) for the product TPAAm.

\begin{tabular}{cccccc}
\hline $\mathrm{c} \times 10^{2}$ & $\mathrm{I}($ u.a) & $\mathrm{c} \times 10^{2}$ & $\mathrm{I}($ u.a $)$ & $\mathrm{c} \times 10^{2}$ & $\mathrm{I}$ (u.a) \\
\hline 0.000 & 39 & 0.570 & 42.0 & 1.50 & 49.0 \\
0.175 & 41 & 0.700 & 44.0 & 4.70 & 73.0 \\
0.344 & 43 & 1.000 & 45.5 & 1.93 & 85.0 \\
0.510 & 42 & 1.200 & 46.0 & 2.27 & 130 \\
\hline
\end{tabular}

Critical micellar concentration (cmc) of $2.30 \times 10^{-3} \mathrm{~g} / \mathrm{mL}$ was obtained for TPADP and $1.58 \times 10^{-2}$ for TPAAm.

The cmc of TPAAm is 7 times greater than that of TPADP. Analysis of results for concentrations above the cmc (C-Ccmc/I-Icmc according to C-Ccmc) leads to an average mass of 340,000 for TPADP and 32,000 and for TPAAm.

The mass found is given by the relation (2):

$$
\frac{1}{M_{W}}=K\left(\frac{\mathrm{d} n}{\mathrm{~d} c}\right)^{2}\left(I_{r e f}^{90}\right)\left(\frac{C}{\Delta I_{90}}\right)
$$

The number of aggregations is equal to 380 for TPADP and 46 for TPAAm. We can explain this result by some association, but this is only a hypothesis given the low intensities detected for very dilute solutions [15].

This table shows the molecular and thermodynamic properties of solutions (molecular and micellar domain) [16], the critical micelle concentration, the degree of association and aggregation number (n) for the micellar solutions. These results are in good agreement with the literature [13].

A critical micellar concentration (cmc) for TPAAm is $1.58 \times 10^{-2} \mathrm{~g} / \mathrm{mL}$ with " $I$ " intensity equal to 50 (in arbitrary units). Intensity of the solvent " $I_{0}$ ” is 39 (in unit arbitrary).

We see a difference in the behavior of these two surfactants (TPADP and TPAAm). These surfactants are associated by hydrophobic and polar interactions to form agglomerates of varying sizes.

\subsection{Glass Transition Temperature}

Many studies were made by the differential scanning calorimetry (DSC) to determine the phase diagrams and mixtures of polymer systems [17] [18], the thermal properties (DSC) were carried out in a temperature range of $0^{\circ} \mathrm{C}$ to $400^{\circ} \mathrm{C}$. In this temperature range was detected three characteristic temperatures.

The thermal properties of surfactants TPADP and TPAAm were evaluated under nitrogen at atmospheric pressure (Figure 5, Figure 6).

The emulsion of TPADP (Figure 6) shows a weight loss of some 3\%, which is due to the solvent. The presence of two peaks at $103^{\circ} \mathrm{C}$ and $123^{\circ} \mathrm{C}$, even after a second heating, is not due to the evaporation of solvent $(\Delta \mathbf{H}$ $=105 \mathrm{~J} / \mathrm{g})$. They correspond respectively to the crystallization of the mono-and diadduct $(\mathrm{n}=1$ and $\mathrm{n}=2)$. Thermal decomposition will start after $293^{\circ} \mathrm{C}$ and it is maximum at $341^{\circ} \mathrm{C}(\Delta \mathbf{H}=121 \mathrm{~J} / \mathrm{g})$.

Based on these results we can conclude that the surfactant TPADP causes some thermal instability and indi- 


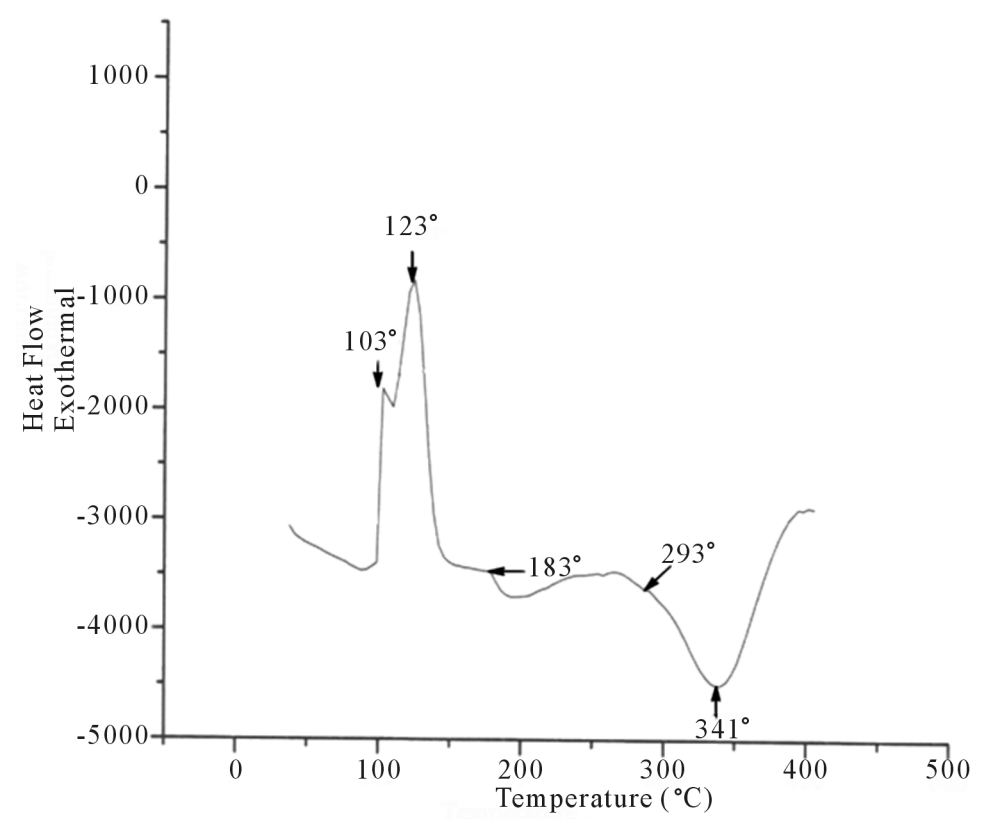

Figure 5. DSC of TPADP surfactant.

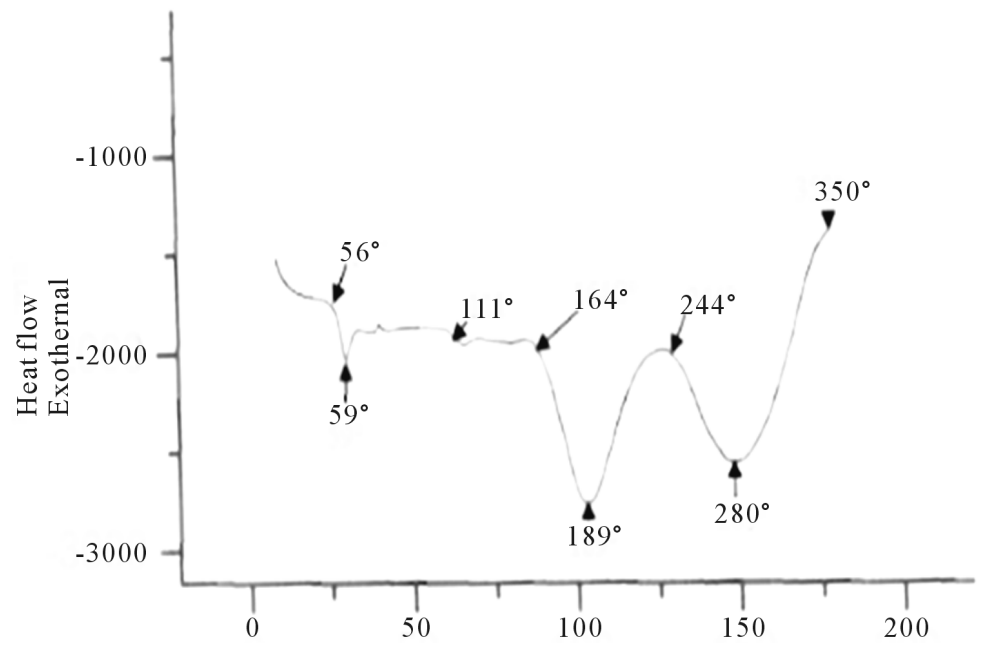

Figure 6. DSC of TPAAm surfactant.

cates an endothermic shift around $183^{\circ} \mathrm{C}$, which corresponds to $\mathrm{Tg}$.

First, the surfactant TPAAm (amino) shows two similar thermal decomposition but opposite direction to the previous one around $189^{\circ} \mathrm{C}$ and the second at $280^{\circ} \mathrm{C}$ and a weight loss of $6.1 \%$ (Figure 6).

The transition temperature Tg of TPAAm is around $111^{\circ} \mathrm{C}$ (Figure 6). This surfactant showed very sharp endothermic peak with a maximum at $189^{\circ} \mathrm{C}$, matching the melting temperature $\mathrm{Tf}$ of the mono-adduct.

It is very interesting to mention that the resulting surfactant TPAAm is thermoplastic. Temperatures $\mathrm{Tf}$ and T'f $\left(280^{\circ} \mathrm{C}\right.$ temperature di-adduct) remain unchanged even after a second heating. It is necessary to note the good correlation between the results of DSC and those given by the literature [19].

\subsection{Application to Marine Environment}

The study of the population depending on the immersion time, gives us an idea on fixing the fouling.

Images that correspond to the seventh month (July 2011) immersion are shown in Figure 7. No attack and no fouling attachment there. The plates have excellent protection against the development of marine organisms. 
In February 2012, organic and inorganic fragments were adsorbed on the surface of the plate P1 (Figure 8), and then bacteria are immobilized in a reversible and irreversible manner, by producing extracellular polymeric substances, which consist predominantly of proteins, polysaccharides, lipids and nucleic acids.

These extracellular polymeric substances used to form an extracellular matrix contributing to the maintenance of adherent bacterial communities [20].

Obtaining the swelling of the resin increases the solubility of the product and deteriorates the paint of the plate P1 (by attachment of the microorganisms).

P2 (Figure 8) plate painted based diethylallyphosphonate develops a certain chemical resistance against the development of the fouling. The swelling is not even after 14 months of immersion. The plate is smooth.

After twenty months of serpula dispersed attaches to any painted surface P1, think of bryozoans shaped lace, layers of very thin green filamentous algae and barnacles medium size (Figure 9) [21].

The biofilm develops, the cells multiply, they communicate via signal molecules and change metabolism to consolidate the biofilm and colonize the surface [22].

The plate P2 has a good protection against the growth of fouling (Figure 9, P2).

The transition to a microbial biofilm more complex community, consisting of spores of algae, barnacles and protozoa, is considered the most important step of fixing biofouling [23].

The last step (thirty months, in June 2013) has the attachment and growth of larger marine invertebrates and macroalgae (Figure 10) [22]. These macrofouling have a metamorphosis and rapid growth.

It is recognized that the presence of different organisms and molecules that serve food on film, influences the subsequent attachment of organisms [24].

The painting represented by the perfluorinated surfactant of diethylallylphosphonate (TPADP) has very good biocidal activity and protection against marine fouling; the plate P2 is always smooth even after 30 months of immersion.

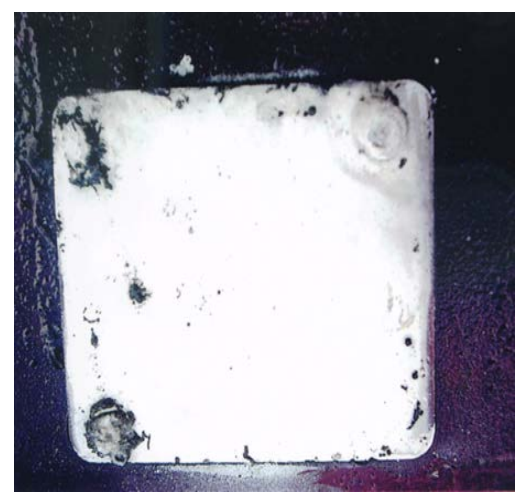

P1

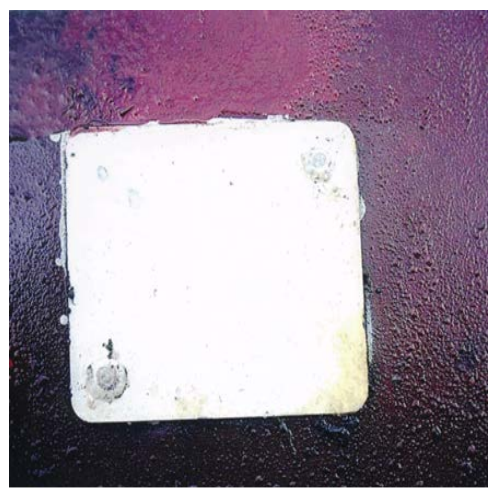

P2

Figure 7. After seven months of immersion, P1 (TPAAm) and P2 (TPADP).

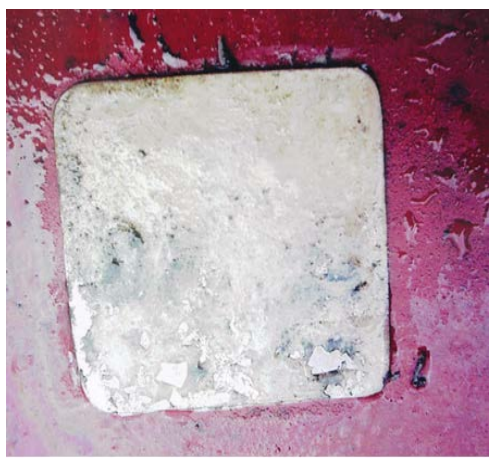

P1

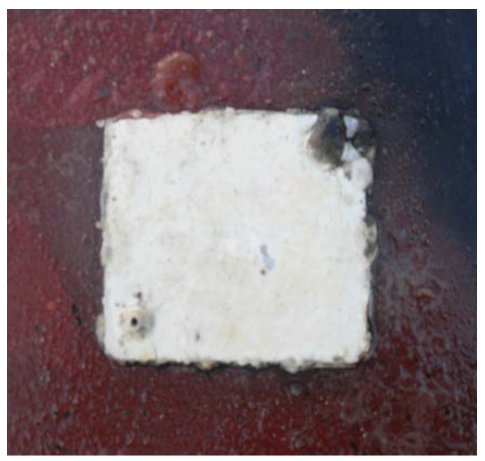

P2

Figure 8. After 14 months of immersion, P1 (TPAAm) and P2 (TPADP). 


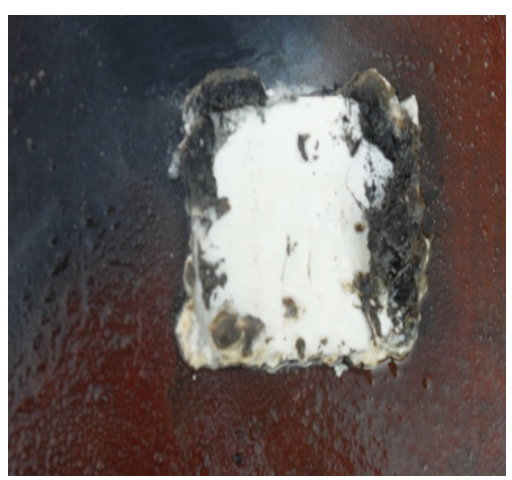

P1

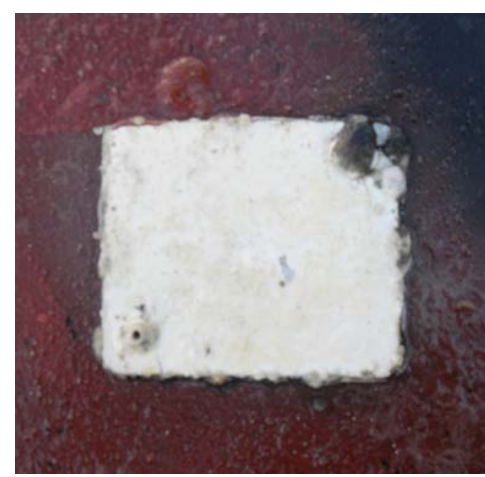

P2

Figure 9. After twenty months of immersion, P1 (TPAAm) and P2 (TPADP) (August 2012).

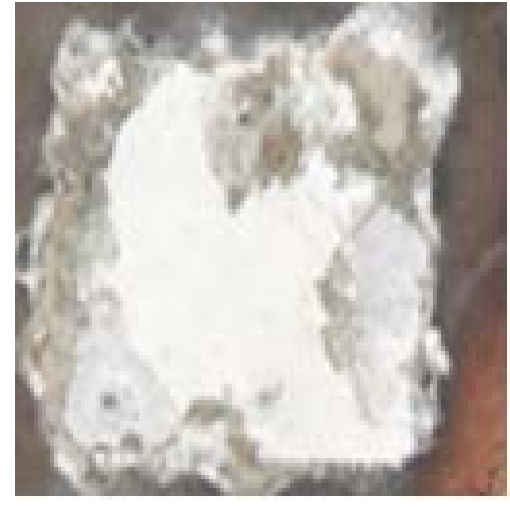

P1

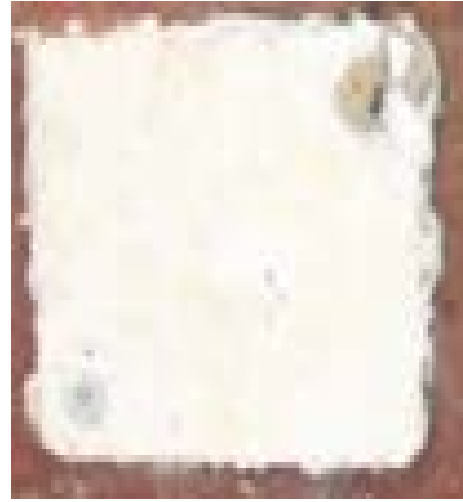

P2

Figure 10. After 30 months of immersion, P1 (TPAAm) and P2 (TPADP) (June 2013).

\section{Conclusions}

As the need to file biocide performance in the field of paints coatings, we have the following results:

1) From the study by the gel permeation chromatography (GPC), we can say that the two chromatograms lead to noticeable results that are qualitatively consistent. In addition to these two surfactants, the reports of the apparent mass to the actual mass (calculated mass) are very similar: 1.58, 1.62 respectively for TPADP products TPAAm. Furthermore, the results of the Table 6 allow us to see a very different behavior for the two surfactants.

2) The surfactant (TPADP) present in the diluted solutions, a significant degree of association $(M=8400)$ and a relatively low cmc whereas micellar solutions are characterized by a large number of aggregation $(n=380)$ in Table 5.

The behavior of surfactant (TPAAm) is different. This product does not appear to be associated with dilute solutions, the cmc is much higher (around 7 times compared to surfactant (TPADP)) and micellar solutions have a number of less aggregation $(\mathrm{n}=53)$ in Table 5 .

The surfactant (TPADP) has beyond the cmc, a large mass. We are in the presence of large micelles repellency with an average level of aggregation. The presence of several different atoms (C, H, F, S, O and P) could explain this result, which is not the case of the surfactant (TPAAm).

3) The glass transition temperatures (Tg) and the thermal properties of the different materials (TPADP) and (TPAAm) were determined by DSC. The most important results are summarized in Table 3, Table 6.

4) In the section of the light scattering (LS), when the volume fraction is increased, the repulsion between micelles tend to space, forming a first array of aggregates. When the volume fraction increases further, the free 
Table 5. Results of measurements of the light scattering before and after the cmc for both surfactants.

\begin{tabular}{|c|c|c|c|}
\hline & Molecular solution before the cmc & cmc g/mL & Micellar solution after the $\mathrm{cmc}$ \\
\hline TPADP & $\begin{array}{c}M=8400 \\
A_{2}=0\end{array}$ & $2.3 \times 10^{-3}$ & $\begin{array}{c}\mathrm{M}=340000 \\
\mathrm{n}=380 \\
\mathrm{~A}_{2}=0.22 \times 10^{-4}\end{array}$ \\
\hline TPAAm & $\begin{array}{l}M=? \\
A_{2}=0\end{array}$ & $1.58 \times 10^{-2}$ & $\begin{array}{c}\mathrm{M}=320000 \\
\mathrm{n}=46 \\
\mathrm{~A}_{2}=6.00 \times 10^{-4}\end{array}$ \\
\hline
\end{tabular}

Table 6. The characteristic temperatures of perfluorinated surfactants.

\begin{tabular}{ccc}
\hline Produits & $\boldsymbol{T}_{g}\left({ }^{\circ} \mathbf{C}\right)$ & $T_{f}$ et $T_{f}^{\prime}\left({ }^{\circ} \mathbf{C}\right)$ \\
TPADP & 183 & 341 \\
TPAAm & 111 & $189^{\circ} \mathrm{C}$ et $280^{\circ} \mathrm{C}$ \\
\hline
\end{tabular}

energy required to change the curvature of the surface can be reduced by the passage of geometry to another.

These arguments given previously explained, the preferred geometry is a spherical micelle [25].

5) At the end of the results obtained from a 30-month immersion, it seems that the color of the plate P1 has changed, this is due to the transformation of microorganisms present on the plate. This fouling is spread over the entire surface with layers of encrusting bryozoans. This mechanism degrades the paint chemically, mechanically and raises the film, which results in the formation of fragments, flakes or blisters. This separates the film from the substrate.

The allyldiéthylphosphonate painting has a very good biocidal activity and better marine antifouling protection, and the plate P2 was always smooth (Figure 10).

The paint sample TPAAm shows a low biocidal activity. It begins to degrade from the 20th month.

\section{Acknowledgements}

The author thanks, Professor Hadj Abdelhafid Sahraoui and his team of Thermophysical of the condensed matter-Maison de la Recherche Environnement Industriel-Dunkerque (University, Lille III).

\section{References}

[1] Dafforn, K.A., Lewis, J.A. and Johnston, E.L. (2011) Antifouling Strategies: History and Regulation, Ecological Impacts and Mitigation. Marine Pollution Bulletin, 62, 62453-62465. http://dx.doi.org/10.1016/j.marpolbul.2011.01.012

[2] Belbachir, B. (1996) Synthèse et étude de macromonomères à activité biocide. Formulation de peintures antisalissures, Mémoire de Magister, Oran.

[3] Evans, S.M., Birchenough, A.C. and Brancato, M.S. (2000) The TBT Ban: Out of the Trying Pan into the Fire. Marine Pollution Bulletin, 40, 204-211. http://dx.doi.org/10.1016/S0025-326X(99)00248-9

[4] Fent, K. (1996) Ecotoxicology of Organotin Compounds. Critical Reviews in Toxicology, 26, 1-117.

[5] Alzieu, C., Thybaud, Y., Heral, M. and Boutier, B. (1980) Evaluation des risques dus à l'emploi des peintures antisalissures dans les zones conchylicoles. Revue des Travaux de l'Institut des Pêches maritimes, 44, 301-348.

[6] Gibbs, P.E. and Bryan, G.W. (1987) TBT Paints and the Demise of the Dog-Whelk Nucella Lapillus (Gastropoda). OCEAN'S 87 Proceedings Organotin Symposium, Halifax, 28 September-1 October 1987, 1482-1487.

[7] Abbott, A., Abel, P.D., Arnold, D.W. and Milne, A. (2000) Cost-Benefit Analysis of the Use of TBT: The Case for a Treatment Approach. Science of The Total Environment, 258, 5-19. http://dx.doi.org/10.1016/S0048-9697(00)00505-2

[8] Jellali, R. (2008) Elaboration de revêtements antifouling par photoréticulation d’oligoisoprènes fonctionnalisés: Etude de leurs activités antibactériennes, antifongiques et antialgale. Thèse de Doctorat, Université du Maine, France.

[9] Kobayshi, Y., Fujino, S. and Kumadaki, I. (1981) Syntheses of Trifluoromethylated Thiadiphosphanorbornadiene and Thiadiphosphole. Journal of the American Chemical Society, 103, 2465-2466. http://dx.doi.org/10.1021/ja00399a079

[10] Kobayshi, Y., Nakano, T., Takahashi, R. and Kumadaki, I. (1979) J. Chem. Soc, Perkin. I, 2253.

[11] Kobayshi, Y., Hamana, H., Fujino, S., Ohsawa, A. and Kumadaki, I. (1979) Studies on Organic Fluorine Compounds. 29. Cycloaddition Reactions of Hexakis(trifluoro4methyl)-1,4-diphospha4barrelene. The Journal of Organic Chemistry, 


\section{4, 4930-4933. http://dx.doi.org/10.1021/jo00394a038}

[12] Bacha, A. and Méghabar, R. (2012) Preparation of Perfluorinated Surfactant Activates for Antifouling Paints. Journal of Surface Engineered Materials and Advanced Technology, 2, 271-277.

[13] Bacha, A. (1996) Thesis, Synthèse et Etude Physicochimique des Tensioactifs Perfluorés Ioniques. University of EsSenia Oran, Algeries.

[14] Chakraborty, S., Vendyopadhyay, S., Dsgupta, S., Mukhopadhyay, R. and Deuri, A.S. (2006) Polymer Testing, 25, 1215. http://dx.doi.org/10.1016/j.polymertesting.2005.09.012

[15] Okamoto, M, Kubo, H. and Kotaba, T. (1998) Elongational Flow-Induced Crystallization and Structure Development in Supercooled Poly(Ethylene Naphthalate). Macromolecules, 31, 4223. http://dx.doi.org/10.1021/ma971713d

[16] Yim, H., Kent, M.S., Matheson, A., Stevens, M.J., Ivkov, R., Satja, S., et al. (2002) Adsorption of Sodium Poly(Styrenesulfonate) to the Air Surface of Water by Neutron and X-Ray Reflectivity and Surface Tension Measurements: Polymer Concentration Dependence. Macromolécules, 35, 9737-9747. http://dx.doi.org/10.1021/ma0200468

[17] Maschke, U., Benmouna, F., Roussel, F., Daoudi, A., Gyselinck, F., Buisine, J.M., Coqueret, X. and Benmouna, M. (2000) Phase Behavior of Electron Beam Cured and Uncured Propoxylated Glyceroltriacrylate/E7 Mixtures. Polymer Bulletin, 44, 577-584. http://dx.doi.org/10.1007/s002890070081

[18] Yen, K.C., Woo, E.M. and Tashiro, K. (2009) Amorphous Phase and Crystalline Morphology in Blend of Two Polymorphic Polyesters: Poly(Hexamethylene Terephthalate) and Poly(Heptamethylene Terephthalate). Polymer, 50, 63126322. http://dx.doi.org/10.1016/j.polymer.2009.10.066

[19] Abdoune, F. (2006) Thèse de Doctorat. Université de Lille I, Lille.

[20] Allison, D.G. (2003) The Biofilm Matrix. Biofouling, 19, 139-150. http://dx.doi.org/10.1080/0892701031000072190

[21] Chapman, B. (2004) La vie sur la plate-forme littorale. Plages à Risque, 3.

[22] Le Magueresse, A. (2005) Balanes: Chtamales, Environnement Littoral-Ifremer/Photo.

[23] Davies, D.G., Parsek, M.R.M., Pearson, J.P., Iglewski, B.H. and Costerton, J.W. (1998) The Involvement of Cell-Cell Signals in the Development of a Bacterial Biofilm. Science, 280, 295-298. http://dx.doi.org/10.1126/science.280.5361.295

[24] Yebra, D.M., Kiil, S. and Dam-Johansen, K. (2004) Antifouling Technology-Past, Present and Future Steps towards Efficient and Environmentally Friendly Antifouling Coatings. Progress in Organic Coatings, 50, 75-104. http://dx.doi.org/10.1016/j.porgcoat.2003.06.001

[25] Bordes, R. (2007) Synthèse Physicochimie et Polymérisation de Tensioactifs Paires d’Ions Dérivés du Norbonène. Thèse de Doctorat, Université de Toulouse III, Toulouse. 